\title{
The effects of individual and combination of asiatic acid and madecassoside derived from Centella asiatica (Linn.) on the viability percentage and morphological changes of mouse macrophage cell lines (J774A.1)
}

\author{
Nurul Hikmah Harun ${ }^{1,2}$, Wan Amir Nizam Wan Ahmad ${ }^{1}$, Rapeah Suppıan ${ }^{1 *}$ \\ ${ }^{1}$ School of Health Sciences, Heath Campus, University of Science Malaysia, 16150, Kubang Kerian, Kelantan, Malaysia. \\ ${ }^{2}$ School of Biomedicine, Faculty of Health Sciences, University of Sultan Zainal Abidin, 21300, Kuala Nerus, Terengganu, Malaysia.
}

\begin{tabular}{l}
\hline ARTICLE INFO \\
\hline Received on: 01/07/2018 \\
Accepted on: 16/08/2018 \\
Available online: $30 / 11 / 2018$
\end{tabular}

Key words:

Asiatic acid, madecassoside, Centella asiatica, cytotoxic, macrophage.

\begin{abstract}
Asiatic acid and madecassoside are the two pentacyclic triterpenoid compounds derived from Centella asiatica (Linn.), which believed to possess major contribution in many related pharmacological activities. This research is conducted to determine the viability and the morphological changes of macrophage cells after treating with individual and combination of the mentioned compounds by using 3-(4,5-dimethylthiazol-2-yl)-2,5-diphenyltetrazolium bromide assay and observing through image analyzer system, respectively. Results displayed that only AA at high doses 25 and $50 \mu \mathrm{g} / \mathrm{ml}$, exhibited mild inhibition of mouse macrophage cells J774A.1 viability with only the latter dose able to alter the morphology of the cells after 24 hours of treatment. Therefore, both compounds either in sole or mix form were harmless to the cells $\left(\mathrm{IC}_{50}>50 \mu \mathrm{g} / \mathrm{ml}\right)$. Interestingly, the combination treatment also enhanced the macrophage cell viability higher than their sole treatment in every concentration. As a consequence, the bioactive compounds at none-cytotoxic level can be applied in any in-vitro further studies such as immunomodulatory and antiinflammatory in order to prove the local traditional claim on the herb and for future benefit in a new prospective of natural product-based drugs development.
\end{abstract}

\section{INTRODUCTION}

Macrophage cells are the main component of innate immunity that involved in initial protection against pathogenic microorganisms that encounter host (Weiss and Schaible, 2015). This phagocyte cells ingest microorganisms into vesicles and destroy them by producing toxic substances through specific process called phagocytosis (Lavin et al., 2015; Newton and Dixit, 2012). An active macrophage cell plays a key role in primary immune responses by producing various mediators such as chemokines, cytokines, and nitrite oxide (NO) to eradicate the infectious agents, and tumor (Duque and Descoteaux, 2014;

\footnotetext{
*Corresponding Author

Rapeah Suppian, Lecturer, School of Health Sciences, Heath Campus, University of Science Malaysia, 16150, Kubang Kerian, Kelantan, Malaysia.E-mail address: rapeah@usm.my
}

Roszer, 2015). The released cytokines by macrophage cells mediate cellular reactions of innate immunity. These soluble proteins include tumor necrosis factor-alpha, interleukin-1-beta (IL-1 $\beta$ ), IL-6, IL-12, and type 1 interferon (IFN) that consist of IFN- $\alpha$ and IFN- $\beta$ that involved in protection against infection (Sica et al., 2015). The secreted cytokines also able to stimulate inflammation and lymphocyte as a response to eliminate microbes (Weiss and Schaible, 2015).

Centella asiatica (Linn.) is commonly known as "pegaga" in Malaysia also popular as "pennywort" and "gotu kola" among American (Lokanathan et al., 2016). The dried whole plant, leaves, and stems are the most beneficial parts in C. asiatica for remedial purposes (Roy et al., 2013). In Malaysia and Indonesia, it is practically eaten uncooked or being consumed in different ways including tea, juice, capsules, and pills. Occasionally, Malaysian mothers will orally take the raw leaf as fresh salad to increase their breastmilk quantity which 
sometimes will be accompanied with sweet potato and coconut milk for reducing its bitterness (Chandrika and Kumara, 2015). In Southeast Asian countries, it has been used traditionally to treat variety of ailments such as diarrhea, rheumatism, inflammation, epilepsy, dehydration, syphilis, and skin diseases (Prakash et al., 2017). In fact, this botanical also become as a drinking water or cooling agent among Chinese and Thai (Zahara et al., 2014). Immunomodulatory study reported that $C$. asiatica also increase immune system (Pal and Pal, 2016).

Major biological active ingredients in $C$. asiatica are believed to come from its pentacyclic triterpenoid glycosides compound such as asiatic acid (AA) and madecassoside (MA) which have been widely studied and attributed to various valuable medicinal properties (Yasurin et al., 2015). According to previous studies, either one or both of the compounds own a wide range of biological functions including as immunomodulatory (Jayathirtha and Mishra, 2004; Mahmood et al., 2016), anti-inflammatory, anti-oxidant (Oyenihi et al., 2017), anti-microbial (Liu et al., 2015), and anti-cancer activities (Kavitha et al., 2015; Li et al., 2016; Zhang et al., 2013). In fact, previous studies were done using Male Sprague-Dawley rats (7 weeks old) induced periodontitis and lipopolysacharides (LPS)-stimulated RAW 264.7 macrophage cells and isolated human gingival fibroblasts (HGFs) from explants of human normal gingival tissue. The methodologies involved were western blot and enzyme-linked immunosorbent assay (ELISA) to measure protein expression levels and pro-inflammatory cytokines, respectively. The in-vitro findings validated that LPS-enhanced NO, IL-6, prostaglandin E2 ( $\left.\mathrm{PGE}_{2}\right)$, and IL-8 secretions were significantly diminished by AA in a dose-response manner after treating with compound at concentrations of 25,50 , and $100 \mu \mathrm{M}$. AA also lowered p65 NF$\kappa \mathrm{B}$ phosphorylation level in LPS-stimulated HGFs. Besides, the in-vivo study showed that LPS-induced $N F-\kappa B$ activation was inhibited by AA treatment (Hao et al., 2017). Other research, Mahmood et al. (2016) reported that the NO production of LPSinduced RAW 264.7 macrophage cells decreased after treatment with 40 and $80 \mu \mathrm{M}$ AA. In contrast, at $160 \mu \mathrm{M}$, this compound exhibited the opposite phenomenon.

Little is known about the cytotoxic effects of the treatment of $\mathrm{AA}$ and $\mathrm{MA}$ derived from $C$. asiatica on the normal mouse macrophage cell lines (J774A.1) thus far which is one of the critical criteria needed in further evaluating the immunomodulatory activities of these compounds. Therefore, this study hypothesized that the individual and combination treatments will show less cytotoxic to macrophage cells. To the best of our knowledge, no specific study related with cytotoxic assessment of combined AA and MA compounds originated from this herb on macrophage cells have been recorded. Hence, the present study aimed to investigate the in-vitro cytotoxic effect of the sole and mixture of mentioned compounds against macrophage cells after 24 hours treatment.

\section{MATERIALS AND METHODS}

\section{Reagents and materials}

Dulbecco's modified eagle medium (DMEM) (Gibco), fetal bovine serum (FBS), penicillin-streptomycin (Gibco), 3-(4,5-dimethylthiazol-2-yl)-2,5-diphenyltetrazolium bromide (MTT) cell count kit (Nacalai Tesque), inverted microscope (Axiovert 25, Zeiss), and image analyzer (PL-A662, Media Cybernetics) were used. All other reagents and chemicals were of the purest commercial grade available.

\section{Cell line}

Mouse macrophage cell lines J774A.1 (code number ATCC\#TIB-67) was purchased from American Type Culture Collection (ATCC, USA). These cells were cultured in complete medium containing fresh DMEM media supplemented with $10 \%$ of FBS and $1 \%$ penicillin-streptomycin. Cells were incubated in the $5 \%$ carbon dioxide incubator at $37^{\circ} \mathrm{C}$.

\section{Plant compounds}

AAcompound with purity more than $98 \%$ and MA(purity $\geq 95 \%$ ) assessed using high performance liquid chromatography (HPLC) derived from $C$. asiatica in stock of $10 \mathrm{mg} /$ vial were purchased from Sigma-Aldrich with product number A2612 and M6949, respectively. Both compounds were stored at $2^{\circ} \mathrm{C}$ to $8^{\circ} \mathrm{C}$. The dilution of both compounds was freshly prepared for each assay using dimethyl sulfoxide (DMSO) and media solutions and the final concentration of DMSO was adjusted to less than $0.1 \%$ $(\mathrm{v} / \mathrm{v})$ to eliminate the cytotoxicity effect by the solvent. Hence, the highest end-point concentration for each individual compound was $50 \mu \mathrm{g} / \mathrm{ml}$.

\section{MTT assay}

The different concentrations of exclusive $(0.78-50 \mu \mathrm{g} / \mathrm{ml})$ or combined $(0.39: 0.39-25: 25 \mu \mathrm{g} / \mathrm{ml})$ of AA and/or MA were applied in this study to determine their cytotoxic effects on the viability of macrophage cells J774A.1. Initially, the cells $\left(2 \times 10^{5}\right.$ cells $\left./ \mathrm{ml}\right)$ during logarithmic growth period were seeded in a 96-well-round bottom microplate overnight and were replaced by fresh pre warmed media. Later, all concentrations of samples were added into each wells and were re-incubated at $37^{\circ} \mathrm{C}$ with $5 \% \mathrm{CO}_{2}$ for 24 hours. The cytotoxicity of samples and LPS, the positive control, were determined using MTT cell count kit based on the guidelines from manufacturer's protocol and Cardoso et al., (2017) method with some modifications. Briefly, $10 \mu \mathrm{l}$ of MTT solution was added to each wells and further incubated for 4 hours in the incubator. After removing the medium, $100 \mu \mathrm{l}$ of solubilization solution (isopropanol with $0.04 \mathrm{~mol} / 1$ hydrocloric acid (HCL)) was put in each wells and then the plate was put on shaker for gentle stirring for 10 minutes to dissolve the forming of precipitated formazans. The optical densities (OD) were measured by plate readers at $570 \mathrm{~nm}$. The viability percentage was calculated using this formula:

$$
\text { Viability percentage }(\%)=\frac{\text { OD sample }- \text { treated cells }}{\text { OD untreated cells }} \times 100
$$

\section{General morphological observations}

First, the cells $\left(2 \times 10^{5}\right.$ cells $\left./ \mathrm{ml}\right)$ were seeded in T-25 flasks overnight. After replacing by fresh pre warmed media the macrophage cells were treated with different concentrations of single $(0.78,6.25$ and $50 \mu \mathrm{g} / \mathrm{ml})$ or mixed $(0.39: 0.39,3.13: 3.13$ and $25: 25 \mu \mathrm{g} / \mathrm{ml}$ ) component of AA and/or madecassosside for 24 hours to determine their cytotoxic effects on morphological 
changes of macrophage cells (J774A.1), separately. The plate were re-incubated at $37^{\circ} \mathrm{C}$ with $5 \% \mathrm{CO}_{2}$ for 2 and 24 hours. The morphological changes of the cells after the treatments were observed using $400 \times$ total magnification of inverted microscope after 2 and 24 hours. This observation was determined based on the basis of method by Vinoj et al., (2015) with slight modifications. Pictures of the cells were taken by using image analyzer.

\section{Statistical analysis}

All the data were analyzed using Statistical Package for the Social Sciences (SPSS) version 23.0. Each sample was measured in triplicate in three independent experiments. The data presented as mean \pm standard error of the mean and the values were obtained from at least three determinations. Data were analyzed using one-way analysis of variance (ANOVA) and Tukey post hoc test for multiple comparisons. All tests were two-tailed and the significance level was set at $p<0.05$.

\section{RESULTS}

Effects of individual and combined treatment of $\mathrm{AA}$ and MA on viability percentage of $\mathbf{J 7 7 4 A} .1$ cells

The data in Figure 1 exhibited that the percentage of viability of macrophage cells reduced in a dose-dependent manner when treated alone and mix compared to untreated cells after the 24 hours. Apparently, the decrease of viability level was greater in cells treated with AA at high dose $(25$ and $50 \mu \mathrm{g} / \mathrm{ml})$ than MA with viability percentage $52.74 \% \pm 0.61 \%$ and $59.05 \% \pm 0.42 \%$ respectively. Meanwhile, the viability of MA treated macrophage cells was more than $80 \%$ in all concentrations used in this study. This indicates that MA did not exert any cytotoxic on macrophage cells between the concentrations $0.78-50 \mu \mathrm{g} / \mathrm{ml}$ within 24 hours treatment.

On the other hand, the cell viability of macrophage treated together with both compounds was significantly higher compared to the exclusive treatment at the same comparative concentrations. Results showed that combined treatments of AA and MA improve the viability of macrophage cells. Four lowest concentration of mixed compounds (3.125:3.125, 1.56:1.56, 0.78:0.78 and 0.39:0.39) $\mu \mathrm{g} / \mathrm{ml}$ exhibited the viability percentages are not significant $(p \geq 0.05$ ) when compared to untreated group. The results indicate the values are very close to the viability percentage of untreated group (100\%).

All data showed the inhibitory concentration 50\% $\left(\mathrm{IC}_{50}\right)$ of each and combination compounds were higher than 50 $\mu \mathrm{g} / \mathrm{ml}$, therefore, it is beyond the indicated measurement in the study. This result suggests that either single or compounding of respective compounds which is lower than $50 \mu \mathrm{g} / \mathrm{ml}$ is harmless to the cells. Cell viability of macrophage also dropped significantly $(p<0.05)$ when treated with LPS, a common drug used as positive control for in-vitro immunomodulatory studies, at concentration of $100 \mathrm{ng} / \mathrm{ml}$.

\section{Effects of individual and combined treatment of AA and MA} on morphological changes of J774A.1 cells

The morphological changes of macrophage cells after single and combination of AA and MA treatment at highest, middle, and lowest concentration in earlier assay were measured through observational method using inverted microscope. Figures 2 and 3 presented the morphological changes of macrophage cells after the individual and combined AA and MA treatment for 2 and 24 hours, respectively. There were no significant changes notified in the morphology of macrophage cell when treated with solely with AA or MA or their combination of AA and madecassoside in almost all concentrations in both durations except $\mathrm{AA}$ at $50 \mu \mathrm{g} / \mathrm{ml}$ and combination substances of $(25: 25) \mu \mathrm{g} / \mathrm{ml}$. All cells were adherent at the bottom surface of flask which indicates no cytotoxic effect on mouse macrophage cells. Furthermore, the cells appeared predominantly in regular round shape and have intact cell wall representing healthy macrophage cells.

Nevertheless, the morphology of macrophage cells after 24 hours treatment with AA at $50 \mu \mathrm{g} / \mathrm{ml}$ showed a significant difference when compared to 2 hours-treated and untreated

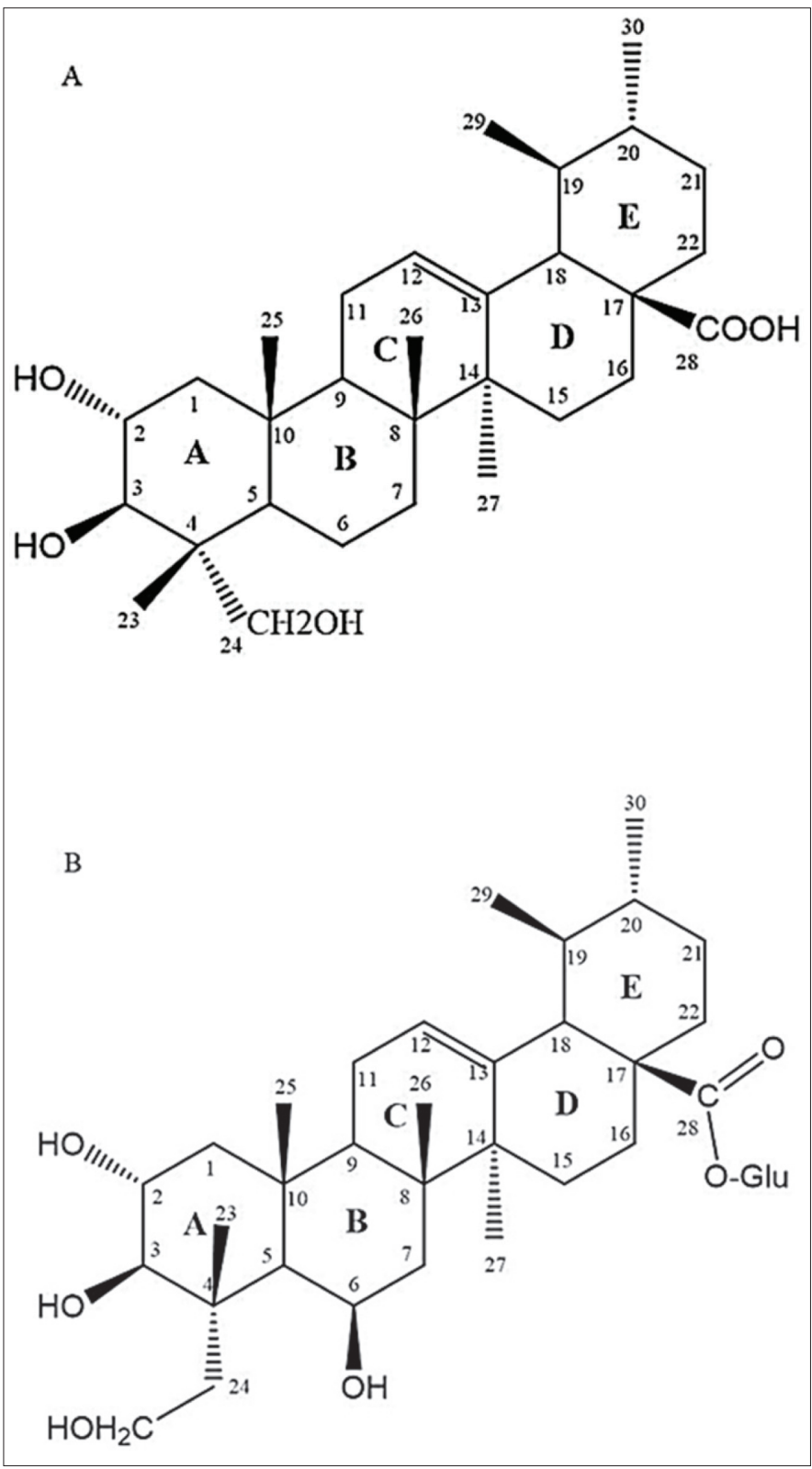

Figure 1. Chemical structures of (A) asiatic acid and (B) madecassoside. 


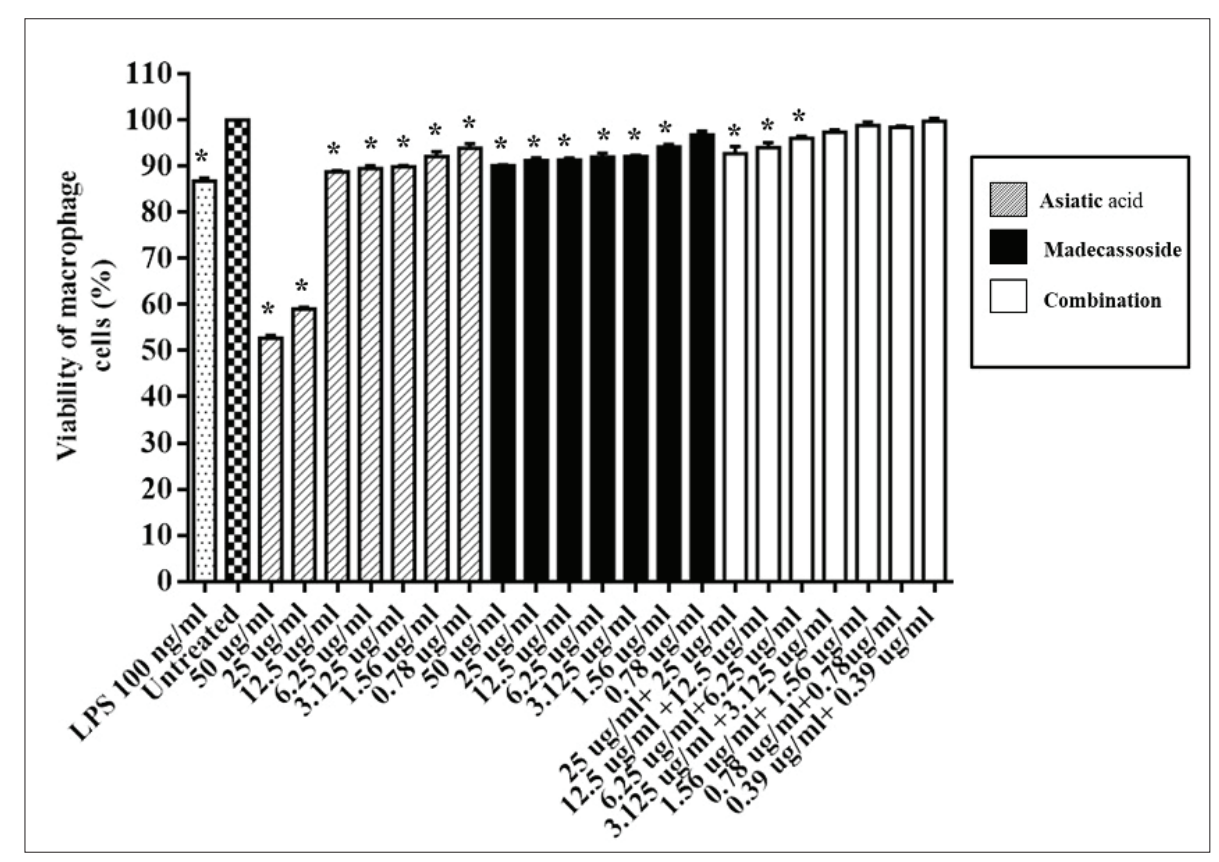

Figure 2. Effects of individual and combination of asiatic acid (AA) and madecassoside (MA) $(* p<0.05)$ on the viability percentage of macrophage cells (J774A.1) when compared to untreated group.

macrophage cells. The observations showed that some of the macrophage cells were detaching at the bottom surface of the flask. The cytotoxicity effects of this compound on the macrophage was characterized by the appearance of attached cells having irregular shapes and damaged cell wall. The morphology of macrophage cells after treated with combination of AA and MA at concentration of $25 \mu \mathrm{g} / \mathrm{ml}$ for each compound after 24 hours presented elongated structure with numerous granules and vacuoles inside as similar with cells treated with LPS $(100 \mathrm{ng} / \mathrm{ml})$. All the data are consistent with the investigations performed by MTT assay.

\section{DISCUSSION}

Today, the use of natural products and their derivatives as a source of immunomodulation drugs has gained more attention due to their lower adverse effects of the drugs towards the treated patients. As an example, a synthetic immunostimulant agent, levamisole was known to give numerous side effects, for instance, flu-like symptoms, allergic manifestations, rashes, and hyperactivities to oneself (Palcoux et al., 1994). Nevertheless, the immunomodulatory agent from natural sources is safe to prevent or treat the immunodeficiency conditions whether from bacterial or viral causes (Kumar et al., 2014). Previous studies have shown that plant-derived phytochemicals such as flavanoids, polysaccharides, lactones, alkaloids, diterpenoids, and glycosides offer alternative for immunomodulating properties. Others substances like curcumin, resveratrol, epigallocathecol-3-gallate, quacertin, colchicine, capsaicin, andrographolide, and genistein also exhibit significant effects on cellular and humoral immunity in in-vitro studies (Jantan et al., 2015). Due to that, it is important to evaluate the cytotoxicity of interest compounds on the immune cells as the first platform along to the discovery of their potential immunomodulatory roles. Instead of that, cytotoxicity assays were among the first in vitro bioassay procedures used to evaluate the toxicity of substances to various cells and tissues (Tolosa et al., 2015).
This study proposed to discover the cytotoxic effects on the individual and combined of AA and MA towards macrophages cells using MTT assay which is a test of metabolic competence evaluated on the assessment of mitochondrial performance of viable cells. As accordance to the principle, the metabolical active cells manage to reduce yellow-color tetrazolium salt MTT into purple formazan crystals via mitochondrial succinate dehydrogenase (Tolosa et al., 2015). The intensity of color at $570 \mathrm{~nm}$ is relatively proportionate to the number of viable cells. In this study, we found that high concentration of AA (25 and $50 \mu \mathrm{g} / \mathrm{ml})$ reduced approximately $40 \%$ of the viability percentage of macrophage cells compared to untreated group. AA at dose $50 \mu \mathrm{g} / \mathrm{mL}$ also altered the morphological changes of this cells after 24 hours treatment when compared to the untreated group.

According to the previous study by Wu et al., (2017), AA appeared to significantly decreases lung cancer cells progress in vitro and in vivo that involved in apoptosis activities mediated through mitochondrial damage. Findings in this study have supported the earlier research when the AA treatment at 10-100 $\mathrm{mM}$ able to decrease the viability of the human glioblastoma cell namely LN-18, U87-MG, and U118-MG, proving that its effectiveness is even higher than temozolomide. In addition, study done by Zhang et al. (2013) presented that the AA also have significantly inhibited RPMI 8226 cells proliferation in a doseand time-dependent manners of 35 and $40 \mu \mathrm{mol} / \mathrm{l}$. The finding also agreed with study done by Liu et al., (2015) illustrated that AA had significant broad-spectrum anti-bacterial activity against both Gram positive and Gram negative bacteria. It was found that AA exhibited high inhibition activity against Escherichia. coli, with mean inhibitory concentration (MIC) and mean bactericidal concentration (MBC) value of 24 and $36 \mu \mathrm{g} / \mathrm{ml}$. This compound also showed strong anti-bacterial activity against Enterococcus faecalis, with MIC and MBC values of 20 and $32 \mu \mathrm{g} / \mathrm{ml}$, respectively. 
AA $50 \mu \mathrm{g} / \mathrm{ml}$

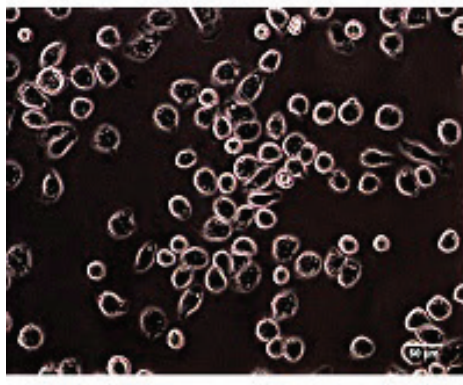

MA $50 \mu \mathrm{g} / \mathrm{ml}$

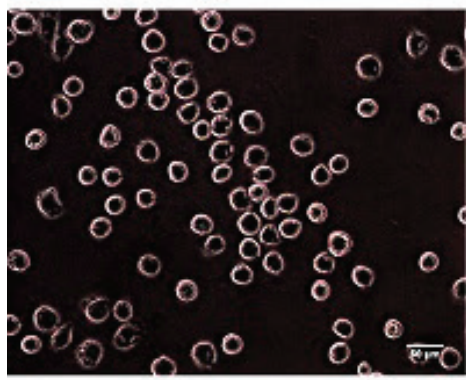

(AA + MA) $25 \mu \mathrm{g} / \mathrm{ml}$

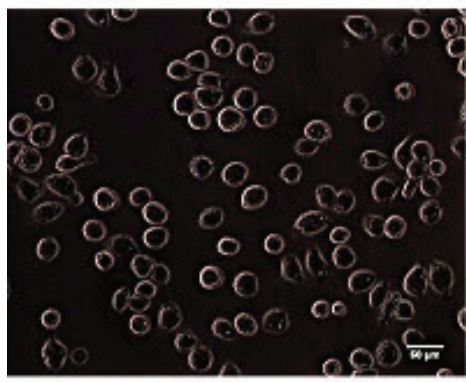

AA $6.25 \mu \mathrm{g} / \mathrm{ml}$

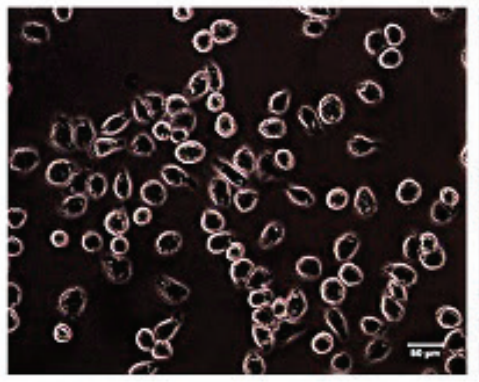

MA 6.25 $\mu \mathrm{g} / \mathrm{ml}$

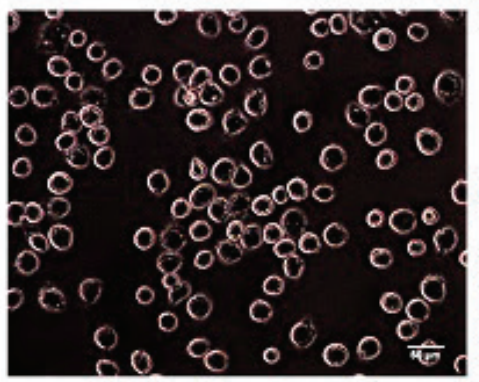

(AA+ MA) $3.13 \mu \mathrm{g} / \mathrm{ml}$

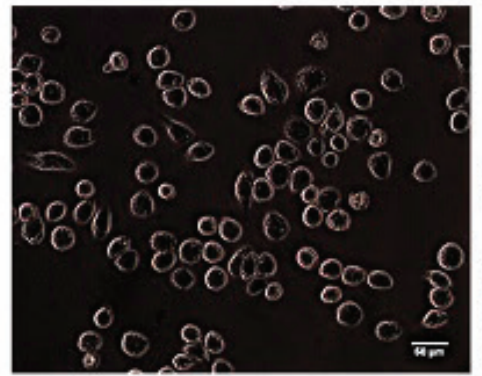

AA $0.78 \mu \mathrm{g} / \mathrm{ml}$

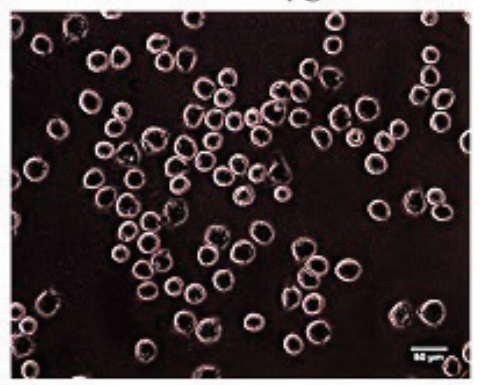

MA $0.78 \mu \mathrm{g} / \mathrm{ml}$

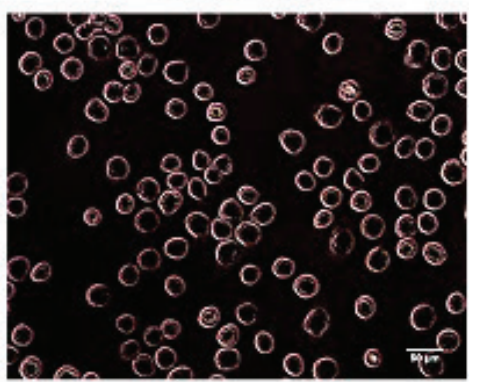

(AA+ MA) $0.39 \mu \mathrm{g} / \mathrm{ml}$

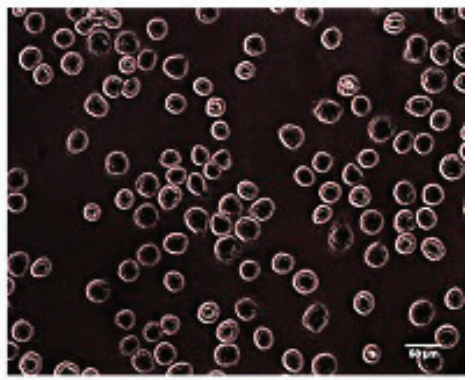

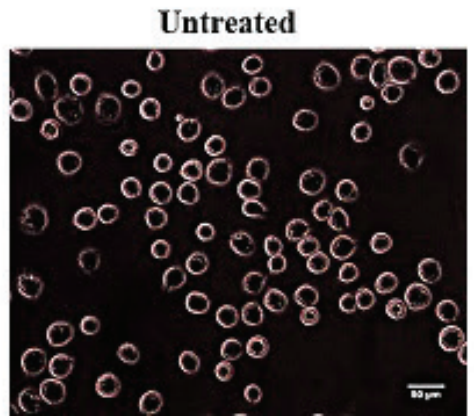

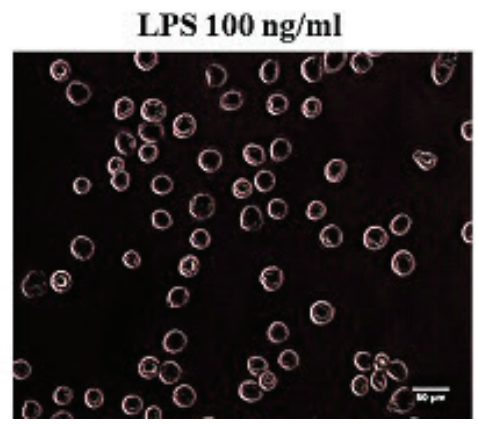

Figure 3. The morphological changes of macrophage cells (J774A.1) after treatment with individual and combination of asiatic acid (AA) and madecassoside (MA) for 2 hours when compared to untreated group.

The results showcased that the combination of both compounds at particular concentration initiated activation effects of macrophage cells and reduced toxicity compared to the single treatment of compound. Those findings might have resulted from the synergistic and chemical interactions of both compounds in improving the viability of the macrophage cells. Synergy is defined as interaction among compounds which produces a better outcome based on the one effect (Nelson and Kursar, 1999). Synergy effects of the mixture of bioactive components contained in plant extracts are claimed to be responsible for the improved effectiveness of many extracts. The mechanisms essential for these synergy effects remained unexplained throughout ancient time (Wagner and Ulrich-Merzenich, 2009). In this study, it is believed that the synergistic action could be from the unique molecular structure of sugar glucose-glucose-rhamnose on MA that involve in enhancing the synergy interactions with AA. In the previous study, the 
AA $50 \mu \mathrm{g} / \mathrm{ml}$

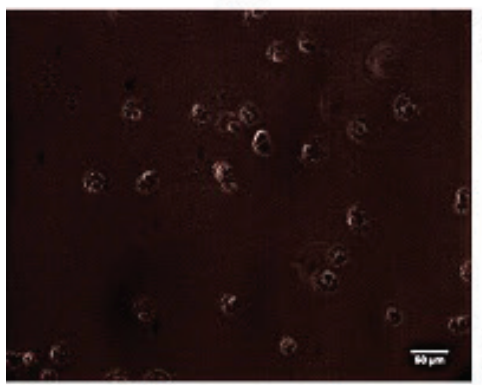

MA $50 \mu \mathrm{g} / \mathrm{ml}$

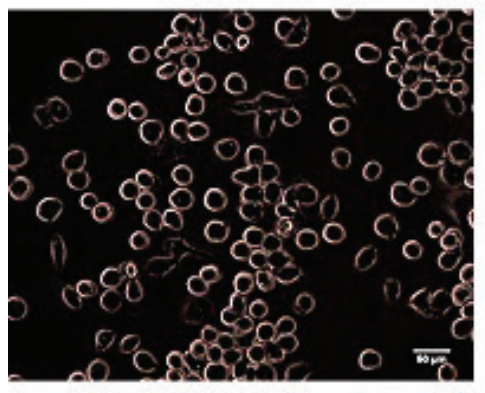

$(\mathrm{AA}+\mathrm{MA}) 25 \mu \mathrm{g} / \mathrm{ml}$

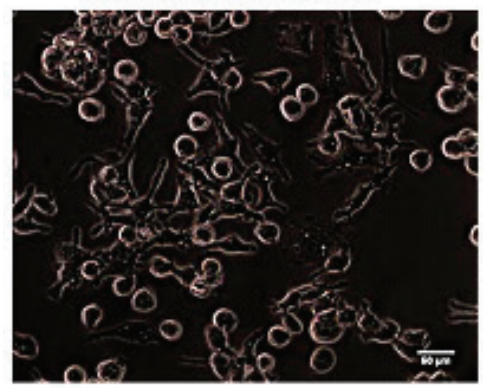

AA $6.25 \mu \mathrm{g} / \mathrm{ml}$

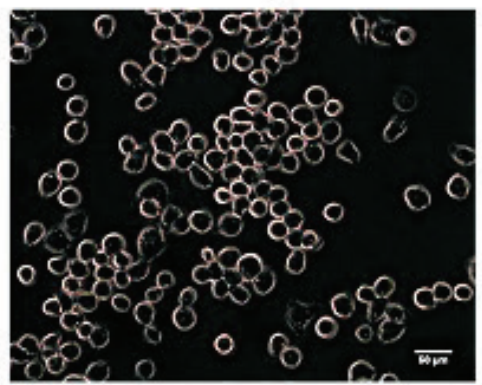

MA $6.25 \mu \mathrm{g} / \mathrm{ml}$

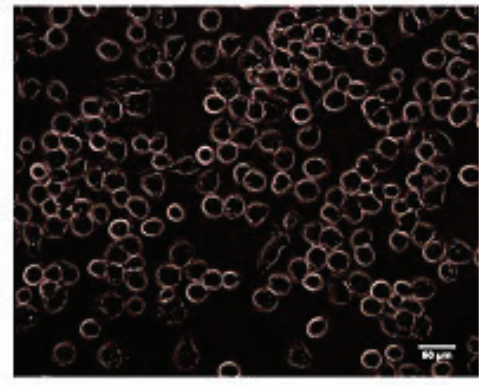

$(\mathrm{AA}+\mathrm{MA}) 3.13 \mu \mathrm{g} / \mathrm{ml}$

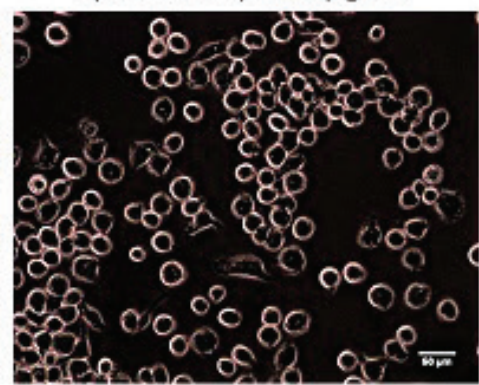

AA $0.78 \mu \mathrm{g} / \mathrm{ml}$

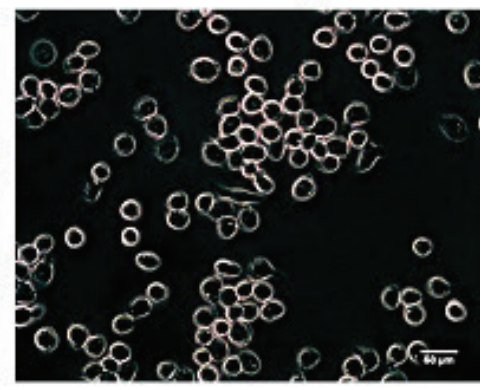

$\mathrm{MA} 0.78 \mu \mathrm{g} / \mathrm{ml}$

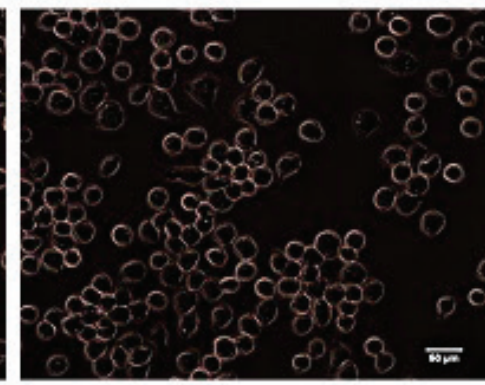

(AA + MA ) $0.39 \mu \mathrm{g} / \mathrm{ml}$

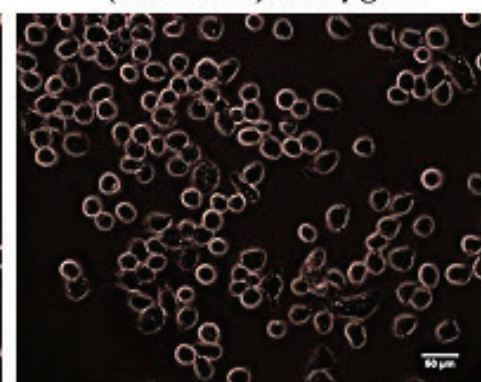

Untreated

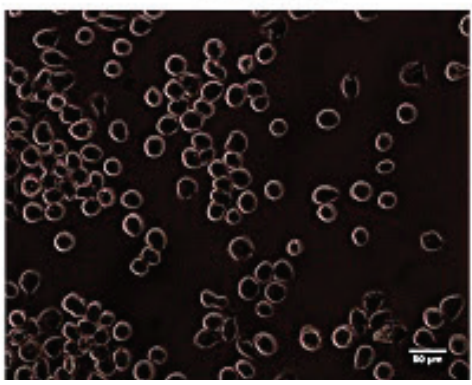

LPS $100 \mathrm{ng} / \mathrm{ml}$

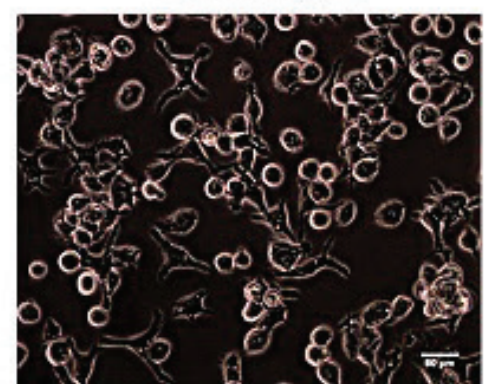

Figure 4. The morphological changes of macrophage cells (J774A.1) after treatment with individual and combination of asiatic acid (AA) and madecassoside (MA) for 24 hours when compared to untreated group.

combination of berberine, epiberberine, palmatine, columbamine, jatrorrhizine, and coptisine exhibited decreased toxicity in HepG2 cell than the effect of single berberine (Chen et al., 2012). However, there is still lack of specific data that involve the synergy activities of mixed components of AA and madecassoside to support the findings of this study. Further studies are required for mechanism and synergistic confirmation of these compounds.

\section{CONCLUSION}

The results of this study revealed that madecassoside compound and its combination with AA did not show any sign of cytotoxicity to the macrophage cells at almost all concentrations in this study $(0.39-50 \mu \mathrm{g} / \mathrm{ml})$. However, the high dose $(25$ and 50 $\mu \mathrm{g} / \mathrm{ml}$ ) of AA exhibited a slight reduction of viability in the cell. These findings present the basis information useful to the advance 
research which requires normal state model containing high viability macrophage cell throughout the study. Later, this will provide a hint to validate the folks claim of the plant and its bioactivities compound to further develop an effective natural product-based drugs.

\section{ACKNOWLEDGMENTS}

The authors gratefully acknowledge the use of services and facilities at School of Health Sciences (PPSK) and School of Dental Sciences (PPSG) of University of Science Malaysia (USM). This study was funded by USM bridging grant (304. PPSK.6316150). The authors also want to thank Ms. Wan Afiqah Syahirah Wan Ghazali, Ms. Azlina Yahya, and Ms. Nor Munirah Zakaria for help and guidance in cell culture maintenance.

\section{CONFLICT OF INTEREST}

The authors declared no conflict of interest.

\section{REFERENCES}

Cardoso EO, Conti BJ, Santiago KB, Conte FL, Oliveira LP, Hernandes RT, Golim MD, Sforcin JM. Phenolic compounds alone or in combination may be involved in propolis effects on human monocytes. J Pharm Pharmacol, 2017; 69(1):99-108.

Chandrika UG, Kumara PAASP. Gotu Kola (Centella Asiatica): nutritional properties and plausible health benefits. Adv Food Nutr Res, 2015; 76:125-57.

Chen HY, Ye XL, Cui XL, He K, Jin YN, Chen Z, Li XG. Cytotoxicity and antihyperglycemic effect of minor constituents from rhizoma coptis in HepG2 cells. Fitoterapia, 2012; 83(1):67-73.

Duque GA, Descoteaux A. Macrophage cytokines: involvement in immunity and infectious diseases. Front Immunol, 2014; 5:1-12.

Hao C, Wu B, Hou Z, Xie Q, Liao T, Wang T, Ma D. Asiatic acid inhibits LPS-induced inflammatory response in human gingival fibroblasts. Int Immunopharmacol, 2017; 50:313-18.

Jantan I, Ahmad W, Bukhari SNA. Plant-derived immunomodulators: an insight on their preclinical evaluation and clinical trials. Front Plant Sci, 2015; 6:655.

Jayathirtha MG, Mishra SH. Preliminary immunomodulatory activities of methanol extracts of Eclipta alba and Centella asiatica. Phytomedicine, 2004; 11(4):361-5.

Kavitha CV, Jain AK, Agarwal C, Pierce A, Keating A, Huber KM, Serkova NJ, Wempe MF, Agarwal R, Deep G. Asiatic acid induces endoplasmic reticulum stress and apoptotic death in glioblastoma multiforme cells both in vitro and in vivo. Mol Carcinogen, 2015; 54(11):1417-29.

Kumar S, Shalini S, Dinesh K, Karunesh K, Renu A. Immunostimulant activity of phyllanthus reticulatus poir: a useful plant for infectious tropical diseases. Asian Pac J Trop Dis, 2014; 4:S491-95.

Lavin Y, Arthur M, Adeeb R, Miriam M. Regulation of macrophage peripheral tissues. Nat Publ Group, 2015; 15(12):731-44.

Li Z, You K, Li J, Wang Y, Xu H, Gao B, Wang J. International immunopharmacology madecassoside suppresses proliferation and invasiveness of HGF-induced human hepatocellular carcinoma cells via. Int Immunopharmacol, 2016; 33:24-32.

Liu WH, Liu TC, Mong MC. Antibacterial effects and action modes of asiatic acid. BioMedicine, 2015; 5(3):16.

Lokanathan Y, Omar N, Puzi ANN, Saim A, Idrus RS. Recent updates in neuroprotective and neuroregenerative potential of Centella asiatica. Malays J Med Sci, 2016; 23(1):4-14.

Mahmood A, Tiwari AK, Sahin K, Kucuk O, Ali S. Triterpenoid saponin-rich fraction of Centella asiatica decreases IL-1 $\beta$ and NF-Kb and augments tissue regeneration and excision wound repair. Turk J Biol, 2016; 40:399-409.
Nelson AC, Kursar TA. Interactions among plant defense compounds: a method for analysis. Chemoecology, 1999; 9(2) 81-92.

Newton K, Dixit VM. Signaling in innate immunity and inflammation. South San Francisco, California: Cold Spring Harbor Laboratory Press, 2012; 1-19.

Oyenihi AB, Novel NC, Oluwafemi OO, Bubuya M. Centella asiatica enhances hepatic antioxidant status and regulates hepatic inflammatory cytokines in type 2 diabetic rats. Pharm Biol, 2017; 55(1):1671-78.

Pal RS, Pal Y. Pharmacognostic review and phytochemical screening of Centella asiatica Linn. J Med Plants Stud, 2016; 4(4) $132-35$.

Palcoux JB, Niaudet P, Goumy P. Side Effects of Levamisole in Children with Nephrosis. Pediatr Nephrol, 1994; 8(2):263-4.

Prakash V, Jaiswal N, Srivastava M. A review on medicinal properties of Centella asiatica. Asian J Pharm Clin Res, 2017; 10(10):69.

Roszer T. Understanding the Mysterious M2 Macrophage through Activation Markers and Effector Mechanisms. Mediators of Inflammation, 2015; 2015: 1-16.

Roy DC, Barman SK, Shaik MM. Current updates on Centella asiatica: phytochemistry, pharmacology and traditional uses. Med Plant Res, 2013; 4:20-36.

Sica A, Marco E, Paola A, Chiara P. Macrophage polarization in pathology. Cell Mol Life Sci, 2015; 72(21):4111-26.

Tolosa L, Donato MT, Gomez-lechon MJ. Chapter 26 general cytotoxicity assessment by means of the MTT assay. Methods Mol Biol, $2015 ; 250: 333-48$

Vinoj G, Rashmirekha P, Avinash S, Baskaralingam V. In vitro cytotoxic effects of gold nanoparticles coated with functional acyl homoserine lactone lactonase protein from Bacillus licheniformis and their antibiofilm activity against proteus species. Antimicrob Agents Chemother, 2015; 59(2):763-71.

Wagner H, Ulrich-Merzenich G. Synergy research : approaching a new generation of phytopharmaceuticals. J Nat Remedies, 2009; 9/2 $121-41$.

Weiss G, Schaible UE. Macrophage defense mechanisms against intracellular bacteria. Immunol Rev, 2015; 264(1):182-203.

Wu T, Ji G, Wenjie G, Jing G, Xixu Z. Asiatic acid inhibits lung cancer cell growth in vitro and in vivo by destroying mitochondria. Acta Pharm Sinica, 2017; B7(1):65-72.

Yasurin P, Sriariyanun M, Phusantisampan T. Review: the bioavailability activity of Centella asiatica. Int J Appl Sci Technol, 2015; 9(1):1-9.

Zahara K, Bibi Y, Tabassum S. Clinical and therapeutic benefits of Centella asiatica. Pure Appl Biol, 2014; 3(4):152-59.

Zhang J, Lisha A, Tingting LV, Xudong J, Fang L. Asiatic acid, a triterpene, inhibits cell proliferation through regulating the expression of focal adhesion kinase in multiple myeloma cells. Oncol Lett, 2013; 6:1762-66.

\section{How to cite this article:}

Harun NH, Ahmad WANW, Suppian R. The effects of individual and combination of asiatic acid and madecassoside derived from Centella asiatica Linn. on the viability percentage and morphological changes of mouse macrophage cell lines (J774A.1). J App Pharm Sci, 2018; 8(11): 109-115. 